\title{
Activity of mycobacterial promoters during intracellular and extracellular growth
}

\author{
Odir A. Dellagostin, $\uparrow$ Giovanna Esposito, Lesley-Jane Eales, \\ Jeremy W. Dale and JohnJoe McFadden
}

\begin{abstract}
Author for correspondence: John Joe McFadden. Tel: +441483300800 ext. 2781. Fax: +44 1483300374 e-mail: j.mcfadden@ surrey.ac.uk
\end{abstract}

Molecular Microbiology Group, School of Biological Sciences, University of Surrey, Guildford, Surrey GU2 5XH, UK

\begin{abstract}
pUS933, a bifunctional Mycobacterium-Escherichia coli translational fusion vector containing an amino-terminally truncated $E$. coli lacZ reporter gene, was constructed. Derivatives of pUS933, containing the promoter, RBS and start codon of the Mycobacterium bovis BCG hsp60 gene, the Mycobacterium leprae $28 \mathrm{kDa}$ gene and the $M$. leprae $18 \mathrm{kDa}$ gene were constructed and introduced into E. coli, Mycobacterium smegmatis and $M$. bovis BCG. $\beta$-Galactosidase activity was measured for mycobacteria grown in liquid culture. Primerextension analysis was used to determine the transcriptional start point for the $18 \mathrm{kDa}$ promoter in $\boldsymbol{M}$. smegmatis. Murine macrophages were infected with recombinant BCG containing the pUS933 derivatives and expression levels were examined, by fluorescence microscopy and fluorometry, during intracellular growth of BCG. Both the BCG $h s p 60$ gene promoter and the $M$. leprae $28 \mathrm{kDa}$ gene promoter gave high levels of $\beta$-galactosidase expression in all situations examined. In contrast, the $M$. leprae $18 \mathrm{kDa}$ promoter fragment gave very low levels of expression in $M$. smegmatis and BCG grown in liquid culture, but in BCG growing within macrophages it was induced to levels almost as high as the other promoters. This indicated that the $18 \mathrm{kDa}$ gene is specifically activated during intracellular growth and may therefore be involved in survival of $M$. leprae within macrophages. This pattern of regulation may be useful for controlling expression of foreign genes in recombinant BCG strains.
\end{abstract}

Keywords: mycobacteria, promoter, gene expression, macrophage

\section{INTRODUCTION}

The mycobacteria are an important group of organisms which includes Mycobacterium tuberculosis and Mycobacterium leprae, the causative agents of tuberculosis and leprosy. BCG (bacille Calmette-Guérin), an avirulent Mycobacterium bovis strain, is currently the world's most widely used vaccine, with a low incidence of serious complications. This and the extraordinary adjuvant properties of mycobacteria make BCG an attractive host strain for the development of recombinant vaccines (Bloom et al., 1990; Stover et al., 1991). During the last few years several vectors have been developed enabling cloning and expression of foreign genes in mycobacteria

† Present address: Centro de Biotecnologia, Universidade Federal de Pelotas, Campus Universitario - Predio 19, Polotas-RS, CEP 96001, Brazil.

Abbreviations: BCG, bacille Calmette-Guérin; FDG, fluorescein-di- $\beta$ galactopyranoside.
(Snapper et al., 1988; Husson et al., 1990; Fuerst et al., 1991; Stover et al., 1991, 1993; Murray et al., 1992; Dellagostin et al., 1993). The development of expression systems in mycobacteria has been achieved by using sequences derived from the region upstream from characterized mycobacterial genes that are presumed to contain the active promoter. Genes that have been used to provide signals for expression of cloned genes in BCG include those encoding members of the conserved Hsp60 and Hsp70 families of stress proteins (Aldovini \& Young, 1991; Stover et al., 1991; Fuerst et al., 1991; Connell et al., 1993; Yasutomi et al., 1993), the secreted $\alpha$-antigen from M. kansasii (Matsuo et al., 1990), a promoter region from Mycobacterium paratuberculosis named $\mathrm{P}_{A N}$ (Murray et al., 1992), the promoter of the groES/groEL1 operon of Streptomyces albus (Winter et al., 1991), the gene encoding the $M$. leprae $18 \mathrm{kDa}$ antigen (Dellagostin et al., 1993), and the sequences encoding the $19 \mathrm{kDa}$ lipoprotein promoter and signal peptide from M. tuberculosis (Stover et al., 1993). 
Expression of recombinant proteins has been demonstrated in vitro and transcriptional start sites have been mapped for a small number of genes (Stover et al., 1991; Murray et al., 1992; Levin \& Hatfull, 1993). However, nothing is known about the in vivo level of expression of these genes. Since BCG is given as a live vaccine, expression of recombinant genes within the parasitized macrophage is likely to be critical for the subsequent immune response.

In this study we describe the development and use of a system that enables assessment of promoter activity during growth inside macrophage cells and we demonstrate the use of this system to analyse the promoter activity of previously characterized mycobacterial gene sequences and to identify new promoters.

\section{METHODS}

Bacterial strains and plasmids. The Glaxo strain of BCG Pasteur was used as a source of $M$. bovis BCG DNA. Escherichia coli DH5 $\alpha$, M. smegmatis $\mathrm{mc}^{2} 155$ (Snapper et al., 1990) and BCG Pasteur were used for characterization of promoter activity. $M$. bovis BCG was grown in Middlebrook $7 \mathrm{H} 9$ broth (Difco) or Middlebrook 7H11 agar (Difco) supplemented with oleic acid albumin dextrose (OADC; Difco), 0.2\% glycerol and 0.05\% Tween 80 (Sigma). E. coli was grown in Nutrient Broth no. 2 (NB) (Oxoid). For solid media, $1 \%(\mathrm{w} / \mathrm{v})$ bacteriological agar (Oxoid) was added. $M$. smegmatis was grown in the same medium as for $E$. coli with the addition of $0.2 \%$ glycerol and $0.05 \%$ Tween 80 . When necessary the medium was supplemented with $15 \mu \mathrm{g}$ kanamycin $\mathrm{ml}^{-1}$ for plasmid selection and $40 \mu \mathrm{g} \mathrm{X}-\mathrm{Gal} \mathrm{m} \mathrm{l}^{-1}$ for identification of recombinant clones with promoter activity. Plasmid pUC18 was obtained from BRL. The plasmid pAL5000 (Labidi et al., 1985a, b; Rauzier et al., 1988) was extracted from $M$. fortuitum and digested with EcoRV.

Enzymes. Restriction enzymes, Taq DNA polymerase and calf intestinal alkaline phosphatase were from Boehringer Mannheim. The Klenow fragment of E. coli DNA polymerase I, T4 polynucleotide kinase and T4 DNA ligase were from BRL.

Construction of the promoter probe vector. The promoterless E. coli lac Z gene was obtained by BamHI digestion of pMC1871 (Shapira et al., 1983). It lacks an RBS and the first eight nonessential N-terminal codons. The BamHI fragment was cloned into the BamHI site of pUC18 to give pUS928. The BamHI fragment from pUC4K (Taylor \& Rose, 1988), containing the kanamycin-resistance gene from $\mathrm{Tn} 903$, was blunt-ended with the Klenow fragment of DNA polymerase I and ligated to SmaIdigested pUS 928 to give pUS929. To provide a mycobacterial origin of replication, pUS929 was digested with ScaI and ligated to EcoRV-digested pAL5000 (Labidi et al., 1985a, b, 1992; Rauzier et al., 1988; Ranes et al., 1990) to generate pUS933 (Fig. 1) which can replicate in E. coli and mycobacteria.

Cloning of characterized promoters. The $h s p 60$ gene promoter from $M$. bovis BCG was amplified by PCR using BCG DNA as template and with the primers PI (5'-TGGCGCatGcGACCACAACG-3') and PII (5'-GTACGCAtgcGTCTTGGCCA-3') ( $S p h I$ site underlined, mismatched bases in lower case). The 404 bp PCR product was digested with $S p h$ I and ligated into the SpbI site of pUS933 to generate pUS934. The $M$. leprae $18 \mathrm{kDa}$ gene Large promoter (including $256 \mathrm{bp}$ of regulatory sequence) was obtained by EcoRI digestion of pUS931 (Dellagostin et al., 1993 ) and the $18 \mathrm{kDa}$ gene Small promoter (including only 136 bp of regulatory sequence) was similarly obtained by EcoRI digestion of pML3 (Booth et al., 1988). Both DNA fragments were blunt-ended by Klenow fragment of DNA polymerase I. The vector pUS933 was digested with $S p h \mathrm{I}$, trimmed back with T4 DNA polymerase and the $18 \mathrm{kDa}$ gene promoters were separately cloned into it to generate pUS935 and pUS936. The $28 \mathrm{kDa}$ gene promoter from $M$. leprae was generated by PCR using $M$. leprae genomic DNA as template. Primer 1: 5'GTCATCGG'T'TGCCTAGAGTA-3'; primer 2: 5' CTTGCATCGGCGTCGGTTCG 3'. The PCR product was blunt-end ligated into the SmaI site of pMC1871 (Shapira et al., 1983). The resulting plasmid was digested with $S a l$ and the fragment containing the $28 \mathrm{kDa}$ gene promoter and the lac $\mathrm{Z}$ gene was excised, blunt-ended and ligated into the EcoRV site of pYUB12 (Snapper et al., 1988) to give pUS170.

Isolation of RNA. RNA isolation from $M$. smegmatis grown under standard conditions in liquid media, was performed by using a RNA extraction kit (Pharmacia) according to the manufacturer's instructions. Briefly, $M$. smegmatis was grown in $50 \mathrm{ml} \mathrm{NB}$ and harvested by centrifugation. The pellet was resuspended in $3 \mathrm{ml}$ extraction buffer (buffered aqueous solution containing guanidinium thiocyanate, $\mathrm{N}$-lauryl sarcosine, and EDTA) and the cells were lysed by sonication. Insoluble debris was removed by centrifugation at $5000 \mathrm{~g}$ for $20 \mathrm{~min}$ and the supernatant was loaded on top of a $2.7 \mathrm{ml}$ cushion of caesium trifluoroacetate and centrifuged at 35000 r.p.m. in a SW50.1 rotor for $12 \mathrm{~h}$ at $15^{\circ} \mathrm{C}$. The RNA pellet was dissolved in water and stored at $-80^{\circ} \mathrm{C}$ as a propan-2-ol precipitate.

Primer-extension analysis. The oligonucleotide primer $5^{\prime}$ ACGGAACGGGTCAGTACGCAT-3', which is complementary to the beginning of the coding sequence of the $18 \mathrm{kDa}$ gene (Booth et al., 1988), was end-labelled with $\left[\gamma^{32} \mathrm{P}\right]$ ATP $(6000 \mathrm{Ci}$ $\mathrm{mmol}^{-1} ; 222 \mathrm{TBq} \mathrm{mmol}{ }^{-1}$ ) using T4 polynucleotide kinase. The radiolabelled primer was purified by chromatography on a SepPak $C_{18}$ (Millipore) column, and the primer-extension reaction was performed as previously described (Sambrook et al., 1989). Products of the primer-extension reaction were separated on a $6 \%(\mathrm{w} / \mathrm{v})$ polyacrylamide/urea gel and visualized by autoradiography. Both strands of the DNA were sequenced with the Sequenase version $2.0 \mathrm{kit}$ (USB) and the same primer.

Transformation of mycobacteria. $M$. smegmatis $\mathrm{mc}^{2} 155$ cells for electroporation were prepared as described by Snapper et al. (1990), with a few modifications. Briefly, $50 \mathrm{ml} \mathrm{NB}$ supplemented with $0.05 \%$ Tween 80 (Sigma) and $0.2 \%$ glycerol in a $250 \mathrm{ml}$ flask was inoculated with $0.5 \mathrm{ml}$ of a saturated culture and incubated on a shaker for $48 \mathrm{~h}$ at $37^{\circ} \mathrm{C}$. After incubating on ice for $30 \mathrm{~min}$, cells were harvested by centrifugation at $4000 \mathrm{~g}$ for $10 \mathrm{~min}$, the pellet was resuspended and washed in $25 \mathrm{ml}$ ice cold $1 \mathrm{mM}$ HEPES, pH 7.0 and then re-centrifuged. After washing the pellet with $10 \mathrm{ml} 10 \%$ (v/v) glycerol, it was resuspended in $2 \mathrm{ml} 10 \%$ glycerol and stored at $-70^{\circ} \mathrm{C}$ in $400 \mu \mathrm{l}$ aliquots. Aliquots $(100 \mu \mathrm{l})$ of cells were mixed with $0.05-0.2 \mu \mathrm{g}$ DNA and transformed in $0.2 \mathrm{~cm}$ electroporation cuvettes, using the BioRad Gene Pulser set at $2.5 \mathrm{kV}, 25 \mu \mathrm{F}$ and $600 \Omega$. The cells were immediately diluted in $0.9 \mathrm{ml} \mathrm{NB}$, transferred to a polypropylene tube (Falcon 2059) and incubated at $37^{\circ} \mathrm{C}$ for $2 \mathrm{~h}$ before plating on $7 \mathrm{H} 11$ medium containing $15 \mu \mathrm{g}$ kanamycin $\mathrm{ml}^{-1}$. Antibiotic-resistant transformants were selected after $3 \mathrm{~d}$ of growth at $37^{\circ} \mathrm{C}$.

For BCG transformation, $7 \mathrm{H} 9$ or $7 \mathrm{H} 11$ medium supplemented with OADC, Tween 80 and glycerol were used. Cells for electroporation were inoculated into $500 \mathrm{ml}$ tissue culture flasks containing $80 \mathrm{ml}$ medium and incubated at $37^{\circ} \mathrm{C}$ for $4 \mathrm{~d}$. Cells were prepared for electroporation as described by Snapper $e t$ al. (1988), and after electroporation the cells were shaken for $4 \mathrm{~h}$ at $37^{\circ} \mathrm{C}$ and then plated and incubated at $37^{\circ} \mathrm{C}$ for 3 weeks. 
$\beta$-Galactosidase assay using ONPG. $\beta$-Galactosidase was assayed in E. coli and mycobacteria as described by Miller (1992): a $0.1 \mathrm{ml}$ volume of a late-exponential phase culture $\left(\mathrm{OD}_{600}\right.$ $0.8-1.2)$ was added to $0.9 \mathrm{ml} \mathrm{Z}$ buffer $\left(6 \mathrm{mM} \mathrm{Na}_{2} \mathrm{HPO}_{4}, 40 \mathrm{mM}\right.$ $\mathrm{NaH}_{2} \mathrm{PO}_{4}, 10 \mathrm{mM} \mathrm{KCl}, 1 \mathrm{mM} \mathrm{MgSO}, 50 \mathrm{mM} \beta$-mercaptoethanol) and permeabilized with $20 \mu \mathrm{l}$ chloroform and $10 \mu \mathrm{l}$ $0.1 \%$ SDS. After vortexing for $10 \mathrm{~s}$ and $5 \mathrm{~min}$ incubation at $28^{\circ} \mathrm{C}, 0.2 \mathrm{ml}^{\circ} \mathrm{mg}$ ONPG $\mathrm{ml}^{-1}$ (Sigma) was added and the incubation was continued at $28^{\circ} \mathrm{C}$. When sufficient yellow colour had developed, the reaction was stopped by adding $0.5 \mathrm{ml} 1 \mathrm{M} \mathrm{Na}_{2} \mathrm{CO}_{3}$ and the incubation time was recorded. After centrifuging for $2 \mathrm{~min}$ at $10000 \mathrm{~g}$, the $\mathrm{OD}_{420}$ was measured and $\beta$-galactosidase activity in Miller units was calculated by the formula: $\left(\mathrm{OD}_{420} \times 1000\right) /\left(t \times v \times \mathrm{OD}_{600}\right)$, where $t$ is the incubation time in minutes and $v$ is the volume in $\mathrm{ml}$ of culture used.

Tissue culture. The mouse macrophage cell line J-774 was grown in RPMI 1640 (Sigma) containing $10 \%(\mathrm{v} / \mathrm{v}$ ) foetal calf serum and $2 \mathrm{mM}$ glutamine. Five millilitres of a suspension of $5 \times 10^{5}$ viable cells $\mathrm{ml}^{-1}$ were used to inoculate a $25 \mathrm{~cm}^{2}$ tissue culture flask, followed by overnight incubation at $37^{\circ} \mathrm{C}$ in $5 \%$ $\mathrm{CO}_{2}$.

Infection of monolayer. Bacterial cultures were diluted directly into fresh tissue culture medium to achieve a rate of infection of about 50 bacteria per macrophage. This inoculating medium was used to replace the growth medium and phagocytosis was allowed to occur for $4 \mathrm{~h}$ at $37^{\circ} \mathrm{C}$ and $5 \% \mathrm{CO}_{2}$. The monolayers were then washed twice with Hank's salt solution (Sigma) to remove non-phagocytosed bacteria, and returned to the incubator with fresh medium containing $50 \mu \mathrm{g}$ gentamicin $\mathrm{ml}^{-1}$ (Sigma) for $24 \mathrm{~h}$, to kill any extracellular bacteria remaining after the washes.

Assay of $\beta$-galactosidase activity in infected macrophages. The $\beta$-galactosidase activity in macrophages infected with recombinant mycobacteria expressing the lac $Z$ gene from different promoters was detected by using the FluoReporter LacZ Detection Kit (Molecular Probes) according to the manufacturer's instructions. Briefly, the infected macrophage cells were removed from the tissue culture flask by trypsin treatment and resuspended in staining medium [PBS ( $0.145 \mathrm{M}$ $\mathrm{NaCl}, 0.15 \mathrm{M}$ sodium phosphate), $4 \%$ foetal calf serum, $10 \mathrm{mM}$ HEPES, $\mathrm{pH} 7 \cdot 2]$ containing $300 \mu \mathrm{M}$ chloroquine (an inhibitor of the endogenous $\beta$-galactosidase) at $10^{7}$ cells $\mathrm{ml}^{-1}$. Cells $(100 \mu \mathrm{l})$ were transferred to a flow cytometer tube and placed in a $37^{\circ} \mathrm{C}$ water bath for $20 \mathrm{~min}$. The substrate, $2 \mathrm{mM}$ fluoresceindi- $\beta$-galactopyranoside (FDG; Molecular Probes) in water, was loaded by adding $100 \mu \mathrm{l}$ pre-warmed $\left(37^{\circ} \mathrm{C}\right)$ solution to the $100 \mu \mathrm{l}$ of cells. After exactly $1 \mathrm{~min}$ at $37^{\circ} \mathrm{C}$, the FDG loading was stopped by adding $1.8 \mathrm{ml}$ ice-cold staining medium and the cells were kept on ice. After $10 \mathrm{~min}, 40 \mu \mathrm{l} 50 \mathrm{mM}$ phenethyl$\beta$-D-thiogalactopyranoside was added to stop the reaction and the cells were analysed by using a flow cytometer FACScan, equipped with an argon ion laser and FACScan research software (Becton Dickinson).

\section{RESULTS}

\section{Construction of the vectors}

The translation fusion vector pUS933 (Fig. 1) containing a truncated $E$. coli lac $Z$ gene without promoter or RBS, was constructed to test mycobacterial expression signals. The $E$. coli lac $Z$ gene has already been successfully used as a reporter gene in mycobacteria (Barletta et al., 1992) allowing the identification of recombinant clones which (a)

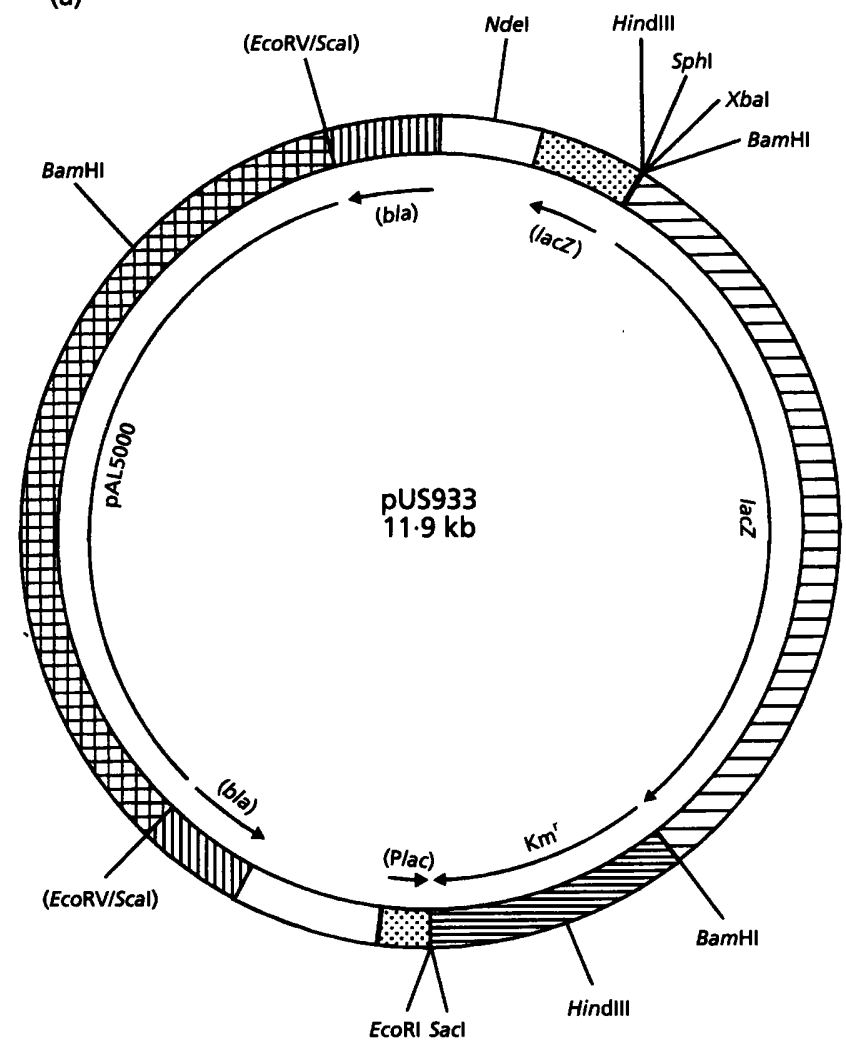

(b)

\section{HindlII Sph Pst Sal Xbal BamHI lacz AAGCTTGCATGCCTGCAGGTCGACTCTAGAGGATCCC GTC}

Fig. 1. (a) Map of the promoter probe vector pUS933. The lacZ reporter gene, the pUC18 lacZ $\alpha$ fragment with its promoter (Plac) and the pUC18 $\beta$-lactamase (b/a) are shown. The construction is described in the text. The constituent segments from different sources are distinguished by different shading. (b) Sequence around the cloning site (arrow indicates translational reading frame).

express enzymically active $\beta$-galactosidase fusion proteins. The kanamycin resistance gene from $\operatorname{Tn} 903$ was used as a selectable marker and the pAL5000 plasmid (Labidi et al., 1985a, b, 1992; Rauzier et al., 1988) provided the mycobacterial origin of replication to generate pUS933. This vector contains two unique restriction sites $(S p h I$ and $X b a \mathrm{I})$ upstream of the promoterless lac $\mathrm{Z}$ gene that are useful for cloning expression signals. Negligible $\beta$ galactosidase activity (less than 2 Miller units) was detected with the vector alone, indicating that promoters present in the vector do not drive significant levels of $\beta$ galactosidase expression. Recombinant plasmids were constructed (Fig. 1) in which this reporter gene was driven by upstream sequences from previously characterized mycobacterial genes, namely the BCG bsp60 gene (Thole et al., 1987), the $M$. leprae $28 \mathrm{kDa}$ antigen-encoding gene which is believed to be iron regulated (Cherayil \& Young, 1988; Dale \& Patki, 1990) and the M. leprae 
Table 1. Promoter fragments examined

\begin{tabular}{|c|c|}
\hline Plasmid & Promoter fragment \\
\hline pUS934 & $\begin{array}{l}0.4 \mathrm{~kb} \text { fragment containing } 383 \mathrm{bp} \text { of } 5^{\prime} \text { regulatory } \\
\text { region plus the first six codons from the BCG } \\
\text { bsp } 60 \text { gene }\end{array}$ \\
\hline pUS935 & $\begin{array}{l}0.34 \mathrm{~kb} \text { fragment containing } 256 \mathrm{bp} \text { of } 5^{\prime} \text { regulatory } \\
\text { region plus the first } 29 \text { codons of the } M \text {. leprae } \\
18 \mathrm{kDa} \text { promoter }\end{array}$ \\
\hline pUS936 & $\begin{array}{l}0.27 \mathrm{~kb} \text { fragment containing } 136 \mathrm{bp} \text { of } 5^{\prime} \text { regulatory } \\
\text { region plus the first } 29 \text { codons of the } M \text {. leprae } \\
18 \mathrm{kDa} \text { promoter }\end{array}$ \\
\hline pUS170 & $\begin{array}{l}0.3 \mathrm{~kb} \text { fragment containing } 276 \mathrm{bp} \text { of the } 5^{\prime} \\
\text { regulatory region plus the first eight codons of the } \\
M \text {. leprae } 28 \mathrm{kDa} \text { antigen gene }\end{array}$ \\
\hline
\end{tabular}

$18 \mathrm{kDa}$ antigen-encoding gene (Booth et al., 1988). Transcriptional start points were known only for the bsp60 gene which in BCG utilizes two transcriptional start sites at positions 183 and $216 \mathrm{bp}$ (tsA and TsB, Fig. 3) upstream of the ATG translational start site (Stover $e t$ al., 1991). Since no promoter sequence had been identified for the M. leprae $18 \mathrm{kDa}$ antigen gene (Booth et al., 1988), two fragments containing either $256 \mathrm{bp}(18 \mathrm{kDa}$ Large promoter) or $136 \mathrm{bp}(18 \mathrm{kDa}$ Small promoter) upstream of the ATG start codon, were examined. Fragments containing these upstream sequences and codons for the first amino acids of the proteins were cloned in-frame with the lac $Z$ gene, producing plasmids pUS934, pUS935, pUS936 and pUS170 (Table 1).

\section{Promoter activity during in vitro growth}

pUS934, pUS935, pUS936 and pUS170 were used to transform E. coli, M. smegmatis and BCG and $\beta$-galactosidase activity was measured in cell extracts. pUS933 is a translational fusion vector and therefore the $\beta$-galactosidase activity obtained is a measure of transcription initiation, promoter strength and the efficiency of the ribosome-binding site. A comparison of expression levels in these species is shown in Table 2. Since the expression in the different hosts may be affected by plasmid copy number, only relative differences between the individual clones are significant. The $b s p 60$ gene promoter gave the highest levels of expression both in $M$. smegmatis and BCG. Surprisingly, the $18 \mathrm{kDa}$ promoter fragments (Large and Small) were relatively strong in E. coli but showed a very low level of expression in M. smegmatis and BCG compared with the $28 \mathrm{kDa}$ gene promoter and the bsp60 gene promoter. The $18 \mathrm{kDa}$ Large promoter which contains $256 \mathrm{bp}$ of upstream sequence shows a significantly higher level of expression than the $18 \mathrm{kDa}$ Small promoter which contains only $136 \mathrm{bp}$ of upstream sequence. This difference in activity was consistent in $E$. coli, $M$. smegmatis and BCG. None of the promoters showed any significant difference in the level of expression in $M$. smegmatis and BCG.

\section{$\beta$-Galactosidase expression in BCG during growth in macrophages}

The recombinant BCG strains were used to infect murine macrophages and the $\beta$-galactosidase activity during intracellular growth was determined. To measure this activity, it was necessary to incubate infected cells with a $\beta$-galactosidase substrate capable of penetrating both the macrophage cell membrane and the mycobacterial cell wall. The fluorescent substrate FDG has previously been shown to be capable of penetrating live mammalian cells in tissue culture (Ikenaka et al., 1990). Preliminary experiments (not shown) demonstrated that FDG was also capable of staining live BCG cells expressing $\beta$ galactosidase constructs.

Monolayers of the murine macrophage cell line J-774 (Snyderman et al., 1977) were infected with mycobacteria. After allowing $4 \mathrm{~h}$ for phagocytosis, the cells were rinsed to remove extracellular bacilli. Ziehl-Neelsen staining confirmed the absence of extracellular bacteria and

Table 2. Comparison of the activities of mycobacterial promoters

\begin{tabular}{|c|c|c|c|c|c|}
\hline & \multicolumn{5}{|c|}{$\beta$-Galactosidase activity } \\
\hline & \multicolumn{3}{|c|}{ Shaken liquid culture (Miller units) } & \multirow{3}{*}{$\begin{array}{c}\begin{array}{c}\text { Intracellular bacteria } \\
\text { (arbitrary fluorescence } \\
\text { units) }\end{array} \\
\text { BCG }\end{array}$} & \multirow[t]{3}{*}{ Activation* } \\
\hline & E. coli & M. smegmatis & BCG & & \\
\hline & & & & & \\
\hline pUS933 (vector) & $0 \cdot 6(0 \cdot 1)$ & $1 \cdot 6(0 \cdot 2)$ & $0 \cdot 2(0 \cdot 5)$ & 0 & 0 \\
\hline pUS170 (28 kDa) & $152(25)$ & $181(38)$ & $155(18)$ & $88(18)$ & $0 \cdot 56$ \\
\hline pUS934 (bsp60) & $136(26)$ & $335(39)$ & $253(34)$ & $156(24)$ & $0 \cdot 61$ \\
\hline pUS935 $18 \mathrm{kDa}-\mathrm{L}$ & $176(24)$ & $20(3)$ & $15(1.5)$ & $75(10)$ & 5 \\
\hline pUS936 $18 \mathrm{kDa}-\mathrm{S}$ & $38(5)$ & $6(1 \cdot 3)$ & $3.8(0.5)$ & $24(11)$ & $6 \cdot 3$ \\
\hline
\end{tabular}

SD are shown in parentheses.

*Activation is the ratio of $\beta$-galactosidase activity in intracellular BCG (fluorescence units) to that in BCG in liquid culture (Miller units). 

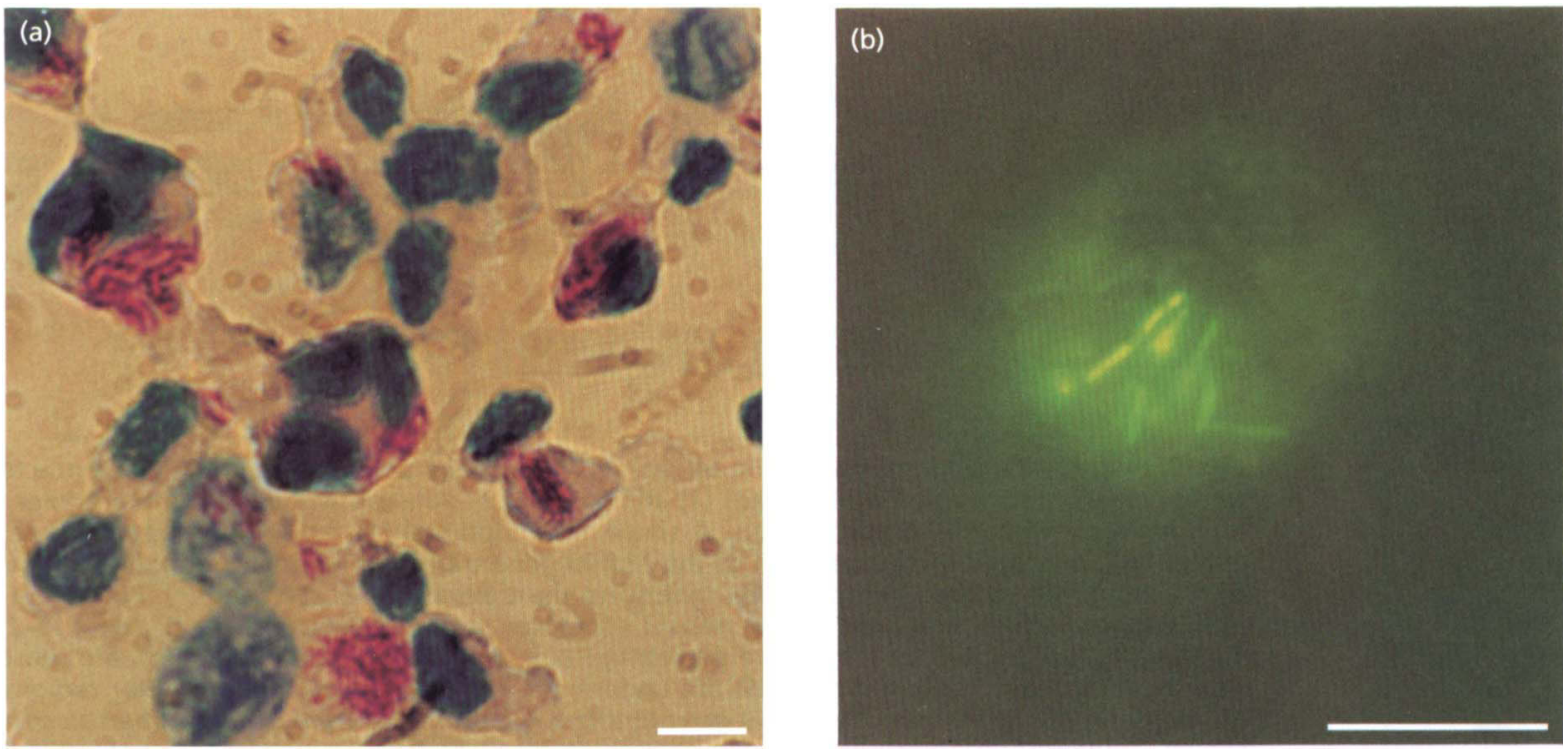

Fig. 2. Intracellular expression of mycobacterial promoters. (a) Ziehl-Neelsen staining of macrophage monolayers infected with recombinant BCG strain. Acid-fast mycobacteria are stained red and the macrophage nuclei are stained blue. (b) Macrophage infected with BCG expressing the $\beta$-galactosidase gene under the control of the $h s p 60$ promoter. Cells were incubated with FDG substrate and photographed with a fluorescent microscope. Mycobacteria expressing the reporter gene appear as yellow filaments. Bars, $25 \mu \mathrm{m}$.

revealed that $75-80 \%$ of macrophages were infected (Fig. 2a). Counting of mycobacteria within macrophages revealed that the numbers of mycobacteria per cell varied from 5 to more than 50 . This range was similar for each of the BCG strains tested and for each experiment. Macrophages were incubated with gentamicin to kill extracellular bacteria, then incubated with FDG and examined by fluorescent microscopy. Intracellular mycobacteria were clearly visible as brightly staining fine rods within the macrophages infected with the recombinant BCG strains (Fig. 2b). No fluorescence was seen with macrophages similarly infected with control BCG cells.

A total of $10^{4}$ cells from each sample were analysed by flow cytometry. The same number of macrophages infected with non-recombinant BCG were also analysed. The relative intensity of fluorescence obtained with control BCG was subtracted from that obtained with the recombinant BCG to give a value for $\beta$-galactosidase activity within the infected macrophages. The means of the results of three separate experiments are shown in Table 2. It is not possible to directly convert between the units of $\beta$-galactosidase activity obtained for extracellular growth (Miller units), with the arbitrary units of fluorescence measured by fluorometry for intracellular activity. To compare intracellular and extracellular expression, we therefore derived a value for relative intracellular activation (in arbitrary units) by dividing the value obtained for intracellular expression (units of fluorescence) by the value (Miller units) for extracellular activity (Table 2). The two $M$. leprae $18 \mathrm{kDa}$ promoter fragments showed the highest relative intracellular activation, i.e. tenfold higher than the activation of the bsp60 gene.

\section{Identification of the $M$. leprae $18 \mathrm{kDa}$ gene promoter}

The $M$. leprae $18 \mathrm{kDa}$ large promoter fragment consistently gave higher levels of $\beta$-galactosidase activity both in vitro and during intracellular growth. This suggested that the large fragment may contain an additional transcriptional start site, as has been reported for the bsp60 promoter (Stover et al., 1991). Since the upstream region of the $18 \mathrm{kDa}$ gene promoter contains a number of possible $E$. coli $\sigma^{70}$ consensus transcription initiation sites, prime-extension analysis was done to identify the promoter region. RNA was extracted from M. smegmatis transformed with either pUS935 or pUS936. A single transcriptional start point located 65 bp upstream of the $18 \mathrm{kDa}$ gene start codon was found for both clones (Fig. 3a). Upstream of the transcriptional start point are -10 and -35 sequences that are similar to consensus $E$. coli $\sigma^{\mathbf{7 0}}$ consensus promoter sequences (Fig 3b). For comparison, Fig. 3 also shows mycobacterial $\sigma^{70}$ and heat shock consensus promoter regions that have been identified by location of transcription start sites.

\section{DISCUSSION}

We have established conditions for examination of mycobacterial promoter activity in mycobacteria grown in vitro and in mycobacteria replicating within macrophages. In this system, a promoter, an RBS and a start codon in the correct reading frame must be provided by the cloned DNA. A similar system has been used to isolate promoters from mycobacteriophages (Barletta et al., 1992), and $M$. tuberculosis DNA (Das Gupta et al., 1993; Timm et al., 1994). Since the consensus sequences and the strengths of mycobacterial RBSs are not fully characterized, we used a 
(a)

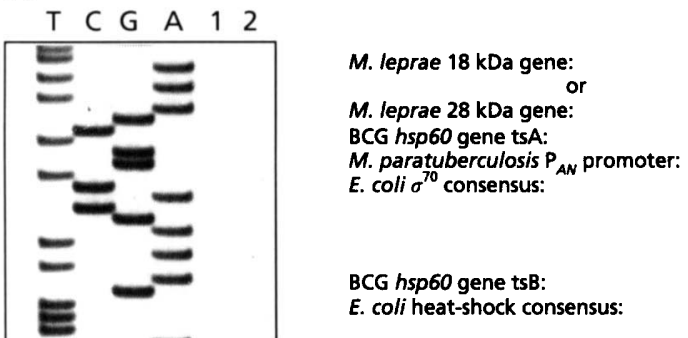

(b)

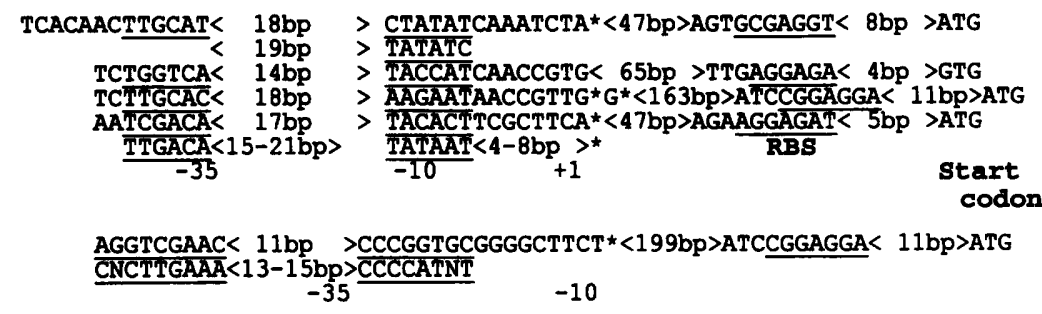

Fig. 3. Primer-extension analysis of the $M$. leprae $18 \mathrm{kDa}$ gene promoter. (a) RNA was extracted from M. smegmatis transformed with pUS935 (1) and pUS936 (2). Analysis was done using a primer located just upstream of the ATG start codon. A single transcriptional start point, the central base of the triplet TAT, is located $65 \mathrm{bp}$ upstream of the $18 \mathrm{kDa}$ gene translational start codon. (b) DNA sequence of the $M$. leprae $18 \mathrm{kDa}$ gene promoter indicating the transcriptional start site (*). Putative -10 and -35 regions, similar to $E$. coli $\sigma^{70}$ consensus promoter sequences $\left(T_{82} T_{84} G_{78} A_{65} C_{54} A_{45}<15-21\right.$ bp $>$ $T_{80} A_{95} T_{45} A_{60} A_{50} T_{96}<4-8 b p>$ *, where percentage base preferences at each position are subscripted; Hawley \& McClure, 1983) and the RBSs are underlined. For comparison, the promoter regions of the $M$. leprae $28 \mathrm{kDa}$ promoter, the $h s p 60$ gene and the $P_{A N}$ promoter from $M$. paratuberculosis are also shown. Transcriptional start sites (*) have been located for the $h s p 60$ gene (Stover et al., 1991; Levin \& Hatfull, 1993), the $P_{A N}$ promoter (Murray et al., 1992) and the $18 \mathrm{kDa}$ gene (this study). The $h s p 60$ gene utilizes two transcriptional start sites in BCG (Stover et al., 1991), tsA (183 bp upstream of the ATG translational start codon: initiation produces two products that differ by one nucleotide) and tsB (216 bp upstream), although only tsA is recognized in $M$. smegmatis (Levin \& Hatfull, 1993). Upstream of tsB are sequences similar to the -10 and $-35 \mathrm{E}$. coli heat-shock consensus promoter sequences and these are shown together with the consensus.

translational rather than a transcriptional probe previously used to study mycobacterial promoters (Kieser et al., 1986; Sirakava et al., 1989; Thomas et al., 1992).

The $b s p 60$ and other mycobacterial promoters have been shown to express antigens that induce an immune response in animal models (de la Cruz et al., 1991; Stover et al., 1991; Murray et al., 1992). However, no studies have previously been done to determine the promoter strength during intracellular growth. Additionally, since the $b s p 60$ promoter gives high levels of expression during in vitro growth, it may be difficult to use this system to clone genes that are toxic to in vitro-grown mycobacteria. For example, attempts to clone the HIV env gene under the control of the $b s p 60$ promoter using a mycobacterial autonomously replicating plasmid vector, were unsuccessful, suggesting that expression of this gene was toxic to BCG (Stover et al., 1991). For the development of a recombinant vaccine it would be useful to have a mycobacterial promoter that is expressed at low levels in vitro but is specifically activated during growth inside macrophages - the environment found by the bacteria once the vaccine is administered. The promoter of the $M$. leprae $18 \mathrm{kDa}$ antigen gene appears to be specifically activated in this way and may therefore be useful in providing expression signals for driving foreign gene expression in recombinant BCG vaccines.

The intracellular up-regulation found for the $18 \mathrm{kDa}$ gene is consistent with the known characteristic of the protein as a major antigen in natural infection. The $M$. leprae $18 \mathrm{kDa}$ antigen is related to the alpha-crystallin family of low molecular mass heat-shock proteins of unknown function. Homologues of this family of proteins are found in M. tuberculosis (Verbon et al., 1992) and other mycobacteria (Booth et al., 1993). The production of a homologous protein found in Mycobacterium babana was found to increase in response to heat shock (Lamb et al., 1990); however this was not found for the M. tuberculosis homologue (Verbon et al., 1992). We demonstrated that in $M$. smegmatis, the $M$. leprae $18 \mathrm{kDa}$ gene utilizes a single transcriptional start point located 66 bp upstream of the start codon. Immediately upstream of the transcriptional start point are putative -10 and -35 sequences that are similar to $E$. coli $\sigma^{70}$ consensus promoter sequences, indicating that in $M$. smegmatis during growth in liquid culture, the $18 \mathrm{kDa}$ gene was transcribed by RNA polymerase associated with the major vegetative sigma factor of $M$. smegmatis. However, the region of the $18 \mathrm{kDa}$ gene promoter (CTATATC) containing the putative -10 sequence, when aligned with the $E$. coli -10 hexamer consensus sequence (TATAAT), shows a mismatch at either the first or the last $T$ residue, both of which are highly conserved in $E$. coli (Fig. 3c). An alternative interpretation is that the functional $18 \mathrm{kDa}-10$ sequence is a pentamer (TATAT). Since little is known of mycobacterial promoter structure, it is impossible to assess the significance of this finding. Further studies involving site-directed mutagenesis will be done to identify critical bases within the promoter region. Both the large and the small upstream 'promoter' fragments used in the reporter probe experiments were shown to utilize the same transcriptional start point, and therefore the difference between the level of expression found with these fragments cannot be due to the use of an additional transcriptional start point in the large fragment. A third recognition element, called the UP element, and a region adjacent to the UP element that contains binding sites for 
the activator protein Fis have been found to extend some E. coli promoter regions to 150 bp upstream (Ross et al., 1993).

The system described here will allow assessment of intracellular expression of genes from both $M$. leprae, $M$. tuberculosis and other mycobacterial pathogens. Genes that are selectively expressed during intracellular growth may be involved in intracellular survival and virulence of $M$. tuberculosis and $M$. leprae. Their identification may therefore provide new targets for chemotherapy, immunotherapy and/or prophylaxis.

\section{ACKNOWLEDGEMENTS}

O.A.D. is grateful to the Brazilian National Council for Scientific and Technological Development (CNPq) for a PhD scholarship.

\section{REFERENCES}

Aldovini, A. \& Young, R. A. (1991). Humoral and cell-mediated immune responses to live recombinant BCG-HIV vaccines. Nature 351, 479-482.

Barletta, R. G., Kim, D. D., Snapper, S. B., Bloom, B. R. \& Jacobs, W. R., Jr (1992). Identification of expression signals of the mycobacteriophages, Bxb1, L1 and TM4 using the EscherichiaMycobacterium shuttle plasmids pYUB75 and pYUB76 designed to create translational fusions to the lacZ gene. J Gen Microbiol 138, 23-30.

Bloom, B. R., Snapper S. B., Kieser, T. \& Jacobs, W. R. (1990). Development of recombinant BCG vaccines. Semin Virol 1, 21-27.

Booth, R. J., Harris, D. P., Love, J. M. \& Watson, J. D. (1988). Antigenic proteins of Mycobacterium leprae, complete sequence of the gene for the $18 \mathrm{kDa}$ protein. J Immunol 140, 597-601.

Booth, R. J., Williams, D. L., Moudgil, K. D., Kamal, D., Noonan, L. C., Grandison, P. M., McKee, J. J., Prestidge, R. L. \& Watson, J. D. (1993). Homologs of Mycobacterium leprae 18-kilodalton and Mycobacterium tuberculosis 19-kilodalton antigens in other mycobacteria. Infect Immun 61, 1509-1515.

Cherayil, B. J. \& Young, R. A. (1988). A $28-\mathrm{kDa}$ protein from Mycobacterium leprae is a target of the human antibody response in lepromatous leprosy. J Immunol 141, 4370-4375.

Connell, N. D., Medina Acosta, E., McMaster, W. R., Bloom, B. R. \& Russell, D. G. (1993). Effective immunization against cutaneous leishmaniasis with recombinant bacille Calmette-Guérin expressing the Leishmania surface proteinase gp63. Proc Natl Acad Sci USA 90, 11473-11477.

de la Cruz, V. F., Stover, C. K., Benson, L. A., Palasynski, S. R., Fuerst, T. R., Young, J. F., Pearce, E., Jacobs, W. R., Jr \& Bloom, B. R. (1991). Humoral and cellular immune response to recombinant Mycobacteria (BCG). In Vaccines 91. Cold Spring Harbor, NY: Cold Spring Harbor Laboratory.

Dale, J. W. \& Patki, A. (1990). Mycobacterial gene expression and regulation. In Molecular Biology of Mycobacteria, pp. 173-198. Edited by J. J. McFadden. London: Academic Press.

Das Gupta, S. K., Bashyam, M. D. \& Tyagi, A. K. (1993). Cloning and assessment of mycobacterial promoters by using a plasmid shuttle vector. J Bacteriol 175, 5186-5192.

Dellagostin, O. A., Wall, S., Norman, E., O'Shaughnessy, T., Dale, J. W. \& McFadden, J. J. (1993). Construction and use of integrative vectors to express foreign genes in mycobacteria. Mol Microbiol 10, 983-993.
Fuerst, T. R., Stover, C. K. \& de la Cruz, V. F. (1991). Development of BCG as a live recombinant vector system, potential use as an HIV vaccine. Biotechnol Ther 2, 159-178.

Hawley, D. K. \& McClure, W. R. (1983). Compilation and analysis of Escherichia coli promoter DNA sequences. Nucleic Acids Res 8, 2237-2255.

Husson, R. N., James, B. E. \& Young, R. A. (1990). Gene replacement and expression of foreign DNA in mycobacteria. $J$ Bacteriol 127, 519-524.

Ikenaka, K., Fujino, I., Morita, N., Iwasaki, Y., Miura, M., Kagawa, T., Nakahira, K. \& Mikoshiba, K. (1990). Reliable transient promoter assay using fluorescein-di- $\beta$-galactopyranoside substrate. DNA Cell Biol 4, 279-286.

Kieser, T., Moss, M. T., Dale, J. W. \& Hopwood, D. A. (1986). Cloning and expression of Mycobacterium bovis BCG DNA in Streptomyces lividans. J Bacteriol 168, 72-80.

Labidi, A., David, H. L. \& Roulland-Dussoix, D. (1985a). Restriction mapping and cloning of Mycobacterium fortuitum var. fortuitum plasmid pAL5000. Ann Inst Pasteur Microbiol 136B, 209-215.

Labidi, A., David, H. L. \& Roulland-Dussoix, D. (1985b). Cloning and expression of mycobacterial plasmid DNA in Eschericbia coli. FEMS Microbiol 30, 221-225.

Labidi, A., Mardis, E., Roe, B. A. \& Wallace, R. J. J. (1992). Cloning and DNA sequence of the Mycobacterium fortuitum var. fortuitum plasmid pAL5000. Plasmid 27, 130-140.

Lamb, F. I., Singh, N. B. \& Colston, M. J. (1990). The specific 18kilodalton antigen of Mycobacterium leprae is present in Mycobacterium babana and functions as a heat-shock protein. I Immunol 144, 1922-1925.

Levin, M. E. \& Hatfull, G. F. (1993). Mycobacterium smegmatis RNA polymerase, DNA supercoiling, action of rifampicin and mechanism of rifampicin resistance. Mol Microbiol 8, 277-285.

Matsuo, K., Yamaguchi, R., Yamazaki, A., Tasaka, H., Terasaka, K., Totsuka, M., Kobayashi, K., Yukitake, H. \& Yamada, T. (1990). Establishment of a foreign antigen secretion system in mycobacteria. Infect Immun 58, 4049-4054.

Miller, J. H. (1992). A Short Course in Bacterial Genetics: a Laboratory Manual and Handbook for Escherichia coli and Related Bacteria. Cold Spring Harbor, NY: Cold Spring Harbor Laboratory.

Murray, A., Winter, N., Lagranderie, M., Hill, D. F., Rauzier, J., Timm, J., Leclerc, C., Moriarty, K. M., Gheorghiu, M. \& Gicquel, B. (1992). Expression of Eschericbia coli $\beta$-galactosidase in Mycobacterium bovis BCG using an expression system isolated from Mycobacterium paratuberculosis which induced humoral and cellular immune responses. Mol Microbiol 6, 3331-3342.

Ranes, M. G., Rauzier, J., Lagranderie, M., Gheorghiu, M. \& Gicquel, B. (1990). Functional analysis of pAL5000, a plasmid from Mycobacterium fortuitum: construction of a 'mini' MycobacteriumEscherichia coli shuttle vector. J Bacteriol 172, 2793-2797.

Rauzier, J., Moniz-Periera, J. \& Gicquel-Sanzey, B. (1988). Complete nucleotide sequence of pAL5000, a plasmid from Mycobacterium fortuitum. Gene 71, 315-321.

Ross, W., Gosink, K. K., Salomon, J., Igarashi, K., Zou, C., Ishihama, A., Serverinov, K. \& Gourse, R. (1993). A third recognition element in bacterial promoters: DNA binding by the $\alpha$ subunit of RNA polymerase. Science 262, 1407-1413.

Sambrook, J., Fritsch, E. F. \& Maniatis, T. (1989). Molecular Cloning: a Laboratory Manual, 2nd edn. Cold Spring Harbor, NY: Cold Spring Harbor Laboratory.

Shapira, S. K., Chou, J., Richaud, F. V. \& Casadaban, M. J. (1983). New versatile plasmid vectors for expression of hybrid proteins 
coded by a cloned gene fused to $l a c Z$ gene sequences encoding an enzymically active carboxy-terminal portion of $\beta$-galactosidase. Gene 25, 71-82.

Sirakava, T. D., Bardarov, S. S., Kriakov, J. I. \& Markov, K. I. (1989). Molecular cloning of mycobacterial promoters in E. coli. FEMS Microbiol Lett 59, 153-156.

Snapper, S. B., Lugosi, L., Jekkel, A., Melton, R. E., Kieser, T., Bloom, B. R. \& Jacobs, W. R., Jr (1988). Lysogeny and transformation in mycobacteria: stable expression of foreign genes. Proc Natl Acad Sci US A 85, 6987-6991.

Snapper, S. B., Melton, R. E., Mustafa, S., Kieser, T. \& Jacobs, W. R., Jr (1990). Isolation and characterization of efficient plasmid transformation mutants of Mycobacterium smegmatis. Mol Microbiol 4, 1911-1919.

Snyderman R., Pike, M. C., Fischer, D. G. \& Koren, H. S. (1977). Biologic and biochemical properties of continuous macrophage cell lines P388-D1 and J-774-1. J Immunol 119, 2060-2066.

Stover, C. K., de la Cruz, V. F., Fuerst, T. R., Burlein, J. E., Benson, L. A., Bennett, L. T., Bansal, G. P., Young, J. F., Lee, M. H., Hatfull, G. G., Snapper, S. B., Garletta, R. G., Jacobs, W. R., Jr \& Bloom, B. R. (1991). New use of BCG for recombinant vaccines. Nature 351, 456-460.

Stover, C. K., Bansal, G. P., Hanson, M. S., Burlein, J. E., Palaszynski, S. R., Young, J. F., Koenig, S., Young, D. B., Sadziene, A. \& Barbour, A. G. (1993). Protective immunity elicited by recombinant bacille Calmette-Guérin (BCG) expressing outer surface protein A (OspA) lipoprotein, a candidate Lyme disease vaccine. J Exp Med 178, 197-209.

Taylor, L. A. \& Rose, R. E. (1988). A correction in the nuceotide sequence of the $\operatorname{Tn} 903$ kanamycin resistance determinant in pUC4K. Nucleic Acids Res 16, 358.

Thole, J. R., Keulen, W. J., Dolk, A. H. J., Groothuis, D. G., Berwald, L. G., Tiesjema, R. H. \& van Embden, J. D. A. (1987). Characterization, sequence determination, and immunogenicity of a 64-kilodalton protein of Mycobacterium bovis BCG expressed in Escherichia coli K-12. Infect Immun 55, 1466-1475.

Thomas, T. J., Andrews, R. E., Jr \& Thoen, C. O. (1992). Molecular cloning and characterization of Mycobacterium paratuberculosis promoters in Escherichia coli. Vet Microbiol 32, 351-362.

Timm, J., Mong Lim, E. \& Gicquel, B. (1994). Escherichia colimycobacteria shuttle vectors for operon and gene fusions to $l a c Z$, the pJEM series. J Bacteriol 176, 6749-53.

Verbon, A., Hartskeerl, R. A., Schuitema, A., Kolk, A. H., Young, D. B. \& Lathigra, R. (1992). The 14,000-molecular-weight antigen of Mycobacterium tuberculosis is related to the alpha-crystallin family of low-molecular-weight heat shock proteins. $J$ Bacteriol 174, 1352-1359.

Winter, N., Lagranderie, M., Rauzier, J., Temm, J., Leclerc, C., Guy, B., Kieny, M. P., Gheorghiu, M. \& Gicquel, B. (1991). Expression of heterologous genes in Mycobacterium bovis BCG, induction of a cellular response against HIV-1 Nef protein. Gene 109, 47-54.

Yasutomi, Y., Koenig, S., Haun, S. S., Stover, C. K., Jackson, R. K., Conard, P., Conley, A. J., Emini, E. A., Fuerst, T. R. \& Letvin, N. L. (1993). Immunization with recombinant BCG-SIV elicits SIVspecific cytotoxic T lymphocytes in rhesus monkeys. J Immunol 150, 3101-3107.

Received 1 March 1995; revised 9 April 1995; accepted 25 April 1995. 